\title{
Impact of Micronutrients on Fruit Set and Fruit Drop of Winter Season Guava (Psidium guajava L.) cv. Allahabad Safeda
}

\author{
Ram Kumar Yadav, R. B. Ram, Vikas Kumar, M. L. Meena* and Harsh Deep Singh \\ Department of Applied Plant Science (Horticulture), Babasaheb Bhimrao Ambedkar University, Vidya-Vihar, \\ Raebareli Road, Lucknow-226 025, India; drmeena1977@gmail.com
}

\begin{abstract}
A field experiment was carried out at the Horticultural Research Farm of the Department of Applied Plant Science (Horticulture), Babasaheb Bhimrao Ambedkar University during the Rabi season of 2012-2013. The experiment was laid out in Randomized Block Design with 9 treatments, replicated thrice and one branch was taken as a unit. Observations were recorded on growth, physical and quality characters of guava. The maximum fruit set percent (67.43) and fruit drop percent (58.71) were recorded maximum with foliar application of zinc sulphate + borax $0.6 \%$ and zinc sulphate+copper sulphate + borax $0.5 \%$. Therefore, zinc sulphate + borax 0.6 percent and zinc sulphate + copper sulphate + borax $0.5 \%$ may be recommended to guava growers for obtaining better yield and quality during winter season crop of guava cv. Allahabad Safeda under Lucknow conditions.
\end{abstract}

Keywords: Fruit Drop, Fruit Set, Guava, Impact, Micronutrients, Studies, Winter Season

\section{Introduction}

Guava (Psidium guajava L.), is one of the most important fruit crop. It is one of the most important tropical/ sub-tropical fruit, because of its high nutritive value and possibilities of cultivation even under adverse conditions. This belongs to the family Myrtaceae with basic chromosome number $\mathrm{n}=11$, it was introduced by the Portuguese in India during $17^{\text {th }}$ century. It is native to Tropical America, stretching from Mexico to Peru, and gradually became a crop of commercial significance in several countries like Brazil, Mexico, China, Malaysia, the Hawaiian Island, Cuba and India. In India, its commercial cultivation is done in Maharashtra, U.P, M.P and Bihar. However, Maharashtra is the pioneer in guava cultivation. In India, guava covers total area as 205 thousands ha, with an annual production of 2462 thousands Metric tons. The average productivity of guava is $12.0 \mathrm{MT} / \mathrm{ha}$. However, Maharashtra has the largest area covering about 36.0 thousands ha followed by Bihar (29.4 thousands ha), U.P. (14.6 thousands ha).
Maharashtra produces 311.0 thousands MT annually followed by M.P. (280.8 thousands MT) and U.P (241.4 thousands MT). The average productivity is highest in M.P. with 29.0 MT/ha Anonymous (2011). The states of Uttar Pradesh have the major share in area and production next by Maharashtra. While the demand of fruit is rising in the market, thereby to achieve higher yield of better quality fruit with longer storage life become the priority. For improve the quality of fruit at harvest and to enhance the storage life by influencing after the harvest changes, several research workers have used certain pre-harvest treatments. The application of mineral nutrients like calcium nitrate, boric acid and zinc sulphate are known to play a vital role in growth, development, quality and storage of fruits by ${ }^{5,6,9}$. Commercially, a guava produced in Allahabad region of U.P. is best in the world ${ }^{3}$. Guava is one of the cheapest and good sources of vitamin $\mathrm{C}$ and pectin. Guava fruit contains 82.50 per cent water, 2.45 per cent reducing sugar, 2.23 per cent non-reducing sugar, 9.73 per cent total soluble solids, 0.48 per cent ash and $260 \mathrm{mg}$

*Author for correspondence 
Vitamin C per 100 gm of fruit pulp as well as good amount of iron, calcium and phosphorus. These constituents may differ with the cultivar, stage of maturity and season. The guava fruit is good source of pectin $(0.78 \%)$, which is an important constituent of the jelly found by Dhingra ${ }^{4}$. In addition, that the availability of fruits is round the year. The quality of guava fruit is greatly affected by temperature and humidity. The development of sweetness, colour and aroma depends on low temperature and dry atmosphere, because of these facts the fruit quality of winter season is better than rainy season. The foliar application of micronutrients plays vital role in improving the quality and comparatively more effective for rapid recovery of plants under high $\mathrm{pH}$ conditions. Most of the micronutrients are rendered unavailable at high $\mathrm{pH}$ condition. The foliar feeding of fruit trees has gained much importance in recent years, as nutrients applied through soil are needed in higher quantities due to leaching losses and also due to unavailability to the plant because of complex soil reaction. Regular foliar spray of micronutrients is beneficial to increase fruit yield.

\section{Materials and Methods}

The field experiment were carried out at the Horticultural Research Farm of the Department of Applied Plant Science (Horticulture), Babasaheb Bhimrao Ambedkar University, Vidya-Vihar, Rae Bareli Road, Lucknow (U.P.) during the rabi season of 2012-13. The experiment was laid out in RBD with three replications. There were 9 treatments i.e., $\mathrm{T}_{1}$-Control (water), $\mathrm{T}_{2}$ - zinc sulphate (0.6\%) $\mathrm{T}_{3}$ - zinc sulphate $(0.8 \%), \mathrm{T}_{4}$ - borax $(0.5 \%), \mathrm{T}_{5}$ borax ( $1 \%), \mathrm{T}_{6}$ - zinc sulphate $(0.4 \%)+$ borax $(0.4 \%)$ each, $\mathrm{T}_{7}$ - zinc sulphate $(0.6 \%)+$ borax $(0.6 \%)$ each, $\mathrm{T}_{8}$ - zinc sulphate + copper sulphate + borax $(0.3 \%)$ each and $\mathrm{T}_{9}$ - zinc sulphate + copper sulphate + borax $(0.5 \%)$ each have been taken conduct this study. There are following observations were recorded on the basis various parameters i.e., number of flowers per shoot, fruit set, fruit retention, fruit size $(\mathrm{cm})$, fruit weight $(\mathrm{g})$, fruit volume $(\mathrm{ml})$, yield per plant $(\mathrm{kg})$, reducing sugar, total sugars, titratable acidity, ascorbic acid and Total Soluble Solids (TSS). The statistical data wereanalyzed obtained in different set of experiments were calculated as suggested by Panse and Sukhatme ${ }^{7}$.

\section{Results and Discussion}

On the basis of Impact of foliar spray of micronutrients on fruit set (\%) and Impact of foliar spray of micronutrients on fruit drop \% in Table 1, the results are depicted here. The data derived on fruit set percent were subjected to statistical analysis. It is obvious from the foliar spray of micronutrients proved significantly effective in improving the fruit set percent. Highest fruit set percent (67.43) was observed in $\mathrm{T}_{7}$ followed by $\mathrm{T}_{6}$ (63.35). However, the treatments $\mathrm{T}_{4}, \mathrm{~T}_{5}$ and $\mathrm{T}_{2}$ remained considerably at par in this regard. The plant under control, showed considerably lowest fruit set percent (54.80). It was noticed that the fruit drop percentage reduced to the highest in $\mathrm{T}_{7}$ which was closely followed by $\mathrm{T}_{6}$ while highest fruit drop percent (58.71) was observed under control $\left(\mathrm{T}_{1}\right)$. Fruit set percent and fruit drop percentage were influenced considerably with different nutrients as compared to control. The highest number of fruit set percentage (67.43) and minimum fruit drop percentage $(34.40 \%)$ were recorded by foliar spray of zinc Sulphate + borax $(0.6 \%)$ which was followed with lower concentration of zinc sulphate + borax (0.4). Borax response was more positive due to boron which plays an important role in translocation of carbohydrates auxin synthesis to the sink and increased in pollen viability and fertilization. The lowest number of fruit set percent and highest number of fruit drop percentage were recorded under control (water spray). Similar results were also observed by Yadav et al. ${ }^{10}$, Awasthi and $\mathrm{Lal}^{2}$ and Ram et al. ${ }^{8}$ in guava.

Table 1. Impact of foliar spray of micronutrients on fruit set (\%) and fruit drop (\%) of winter season guava cv. Allahabad Safeda

\begin{tabular}{|c|c|c|}
\hline Treatments & Fruit set $(\%)$ & Fruit drop (\%) \\
\hline $\mathrm{T}_{1} \quad$ (Control) & 54.80 & 58.71 \\
\hline $\mathrm{T}_{2} \quad$ (Zinc sulphate $\left.0.6 \%\right)$ & 61.11 & 45.86 \\
\hline $\mathrm{T}_{3} \quad$ (Zinc sulphate $\left.0.8 \%\right)$ & 60.05 & 42.08 \\
\hline $\mathrm{T}_{4} \quad($ Borax $0.5 \%)$ & 63.09 & 36.38 \\
\hline $\mathrm{T}_{5} \quad($ Borax $1 \%)$ & 62.73 & 36.08 \\
\hline $\begin{array}{ll}\mathrm{T}_{6} & \text { (Zinc sulphate }+ \text { Borax }) \\
& \text { each } 0.4 \%\end{array}$ & 63.35 & 35.64 \\
\hline $\begin{array}{ll}\mathrm{T}_{7} & \text { (Zinc sulphate }+ \text { Borax }) \\
& \text { each } 0.6 \%\end{array}$ & 67.43 & 34.40 \\
\hline $\begin{array}{ll}\mathrm{T}_{8} & \left(\mathrm{ZnSO}_{4}+\mathrm{CuSO}_{4}+\right. \\
& \text { Borax }) \text { each } 0.3 \%\end{array}$ & 60.00 & 44.38 \\
\hline $\begin{array}{ll}\mathrm{T}_{9} & \left(\mathrm{ZnSO}_{4}+\mathrm{CuSO}_{4}+\right. \\
& \text { Borax }) \text { each } 0.5 \%\end{array}$ & 59.97 & 46.91 \\
\hline S E m \pm & 0.89 & 1.27 \\
\hline C D (5\%) & 2.67 & 3.82 \\
\hline
\end{tabular}




\section{Conclusion}

The maximum number of fruit set and minimum fruit drop percentage were obtained with foliar spray of zinc sulphate + borax 0.6 percent followed by zinc sulphate + borax 0.4 percent. However, the foliar spray 0.6 percent zinc sulphate + borax proved most effective followed by zinc sulphate + borax 0.4 percent for better fruit set percent. However, zinc sulphate + borax 0.4 percent and zinc sulphate 0.8 percent were equally good. Well pronounced influence of micronutrients was observed with respect to quality of fruit. Therefore, zinc sulphate + borax 0.6 percent and zinc sulphate + copper sulphate + borax $0.5 \%$ may be recommended to guava growers for obtaining better yield and quality during winter season crop of guava cv. Allahabad Safeda under Lucknow conditions.

\section{References}

1. Anonymous. Indian Horticulture Database. Gurgaon, Haryana: National Horticulture Board; 2011.

2. Awasthi P, Lal S. Effect of calcium, boron and zinc foliar sprays on the yield and quality of guava (Psidium guajava L.). Pantnagar J Res. 2009; 7(2):223-5.
3. Chaddha KL. Hand Book of Horticulture. New Delhi: ICAR; 2007.

4. Dhingra MK. Effect of cropping season, stage of maturity and method of extraction on quantity of pectin in guava. J Food Sci Technol. 1979; 21:173-5.

5. Dixit CK, Singh JN, Singh A. Studies on storage of square (Psidium guajava L.) cv Allahabad Safeda. Intern. Seminar on Recent Trend in Hi-tech Hort. \& P.H.T; 2004 Feb 4-6; Kanpur.

6. Jayachandra KS, Srihari D, Reddy YN. Preharvest spray of different source of calcium to improve the shelf life of guava. Indian J Hort. 2005; 62(1):68-70.

7. Panse VG, Sukhatme PV. Statistical Methods of Agricultural Workers. New Delhi: ICAR; 1985.

8. Ram S, Dwivedi TS, Bist LD. Internal fruit necrosis in aonla (Emblica officinalis Gaertn.). Prog Hort. 1977; $8(3): 5-12$.

9. Singh R, Chaturvedi OP, Singh R. Effect of pre harvest spray of zinc, boron and calcium on the physico chemical quality of guava fruits (Psidium guajava L.). Intern. Seminar on Recent Trend on Hi-tech Hort. and P.H.T; 2004 Feb 4-6; Kanpur.

10. Yadav HC, Yadav AL, Yadav DK, Yadav PK. Effect of foliar application of micro-nutrients and $\mathrm{GA}_{3}$ on fruit yield and quality of rainy season guava (Psidium guajava L.) cv. L-49. Plant Archives. 2011; 11(1):147-9. 